Marquette University

e-Publications@Marquette

College of Nursing Faculty Research and

Publications

Nursing, College of

$11-1-2016$

Resilience in Adolescents Who Survived a Suicide Attempt from the Perspective of Registered Nurses in Inpatient Psychiatric Facilities

Denise M. Matel-Anderson

Marquette University, denise.matel-anderson@marquette.edu

Abir K. Bekhet

Marquette University, abir.bekhet@marquette.edu

Accepted version. Issues in Mental Health Nursing, Vol. 37, No. 11 (November 2016): 839-846. DOI.

(C) 2016 Taylor \& Francis. Used with permission. 
NOT THE PUBLISHED VERSION; this is the author's final, peer-reviewed manuscript. The published version may be accessed by following the link in the citation at the bottom of the page.

\title{
Resilience in Adolescents Who Survived a Suicide Attempt from the Perspective of Registered Nurses in Inpatient Psychiatric Facilities
}

\author{
Denise M. Matel-Anderson \\ College of Nursing, Marquette University \\ Milwaukee, WI \\ Abir K. Bekhet \\ College of Nursing, Marquette University \\ Milwaukee, WI
}

\begin{abstract}
The number of deaths by suicide has increased over the last few years. The purpose of this qualitative study is to explore components of resilience in adolescents who survived a suicide attempt from the perspective of nine psychiatric nurses. Resilience was used as a guiding conceptual framework which proposes that resilience is the interplay between risk and protective factors. Three categories emerged including risk factors, protective factors, and future recommendations of suicide prevention strategies. The perspectives gained from this study will help develop nursing interventions for adolescents to overcome risk factors and to build on their protective factors.
\end{abstract}

Issues in Mental Health Nursing, Vol 37, No. 11 (November 2016): pg. 839-846. DOI. This article is @ Informa Healthcare and permission has been granted for this version to appear in e-Publications@Marquette. Informa Healthcare does not grant permission for this article to be further copied/distributed or hosted elsewhere without the express permission from Informa Healthcare. 
While death from other causes has decreased a drastic increase in deaths by suicide has become a national tragedy over the last few years (Fitzpatrick, 2015). The 2014 national statistics indicated that there was a 31\% increase in deaths by suicide from 2000-2011 and for every 12.8 minutes someone in the United States dies as a result of suicide completion (American Foundation for Suicide Prevention, 2015). In 2013, the number of suicides reported was 41,149 making suicide the tenth leading cause of death in the United States. The increase in deaths by suicide became the second leading cause of death for 15 to 19 year olds in 2015, whereas for 10 to 15 year olds suicide continues to be the third leading cause of death (American Foundation for Suicide Prevention, 2015; CDC, 2015a). With the increase in number of suicides, the lack of attention in the American society regarding mental health in general and suicide prevention in particular is alarming (Fitzpatrick, 2015). These findings support the need for developing and implementing suicide prevention strategies targeting the adolescents admitted to inpatient facilities for suicide attempt (SA) and suicide ideation (SI).

Throughout the literature, adolescence is defined as a unique population of individuals, from 10-19 years of age, requiring examination apart from other age groups (WHO, 2013). In 2012, adolescents represented around 41 million persons in the United States and almost $14 \%$ of the population (United States Census Bureau, 2012). Adolescence was recognized as a vulnerable time for youth; it is a time of physical maturation and hormonal changes that can affect feelings and behavior when going through puberty (Blakemore, Burnett, \& Dahl, 2010; WHO, 2015).

Adolescence is a transitional period from the immaturity of childhood to the well-developed mature adulthood (Bekhet, ElGuenidi, \& Zauszniewski, 2011). Studies have found specific changes in the development of the adolescent brain before adulthood in the areas of memory and where the "processes of thought" are located (NIH, 2011). These changes continue until the early 20s when the human brain images begin to represent an adult brain (NIH, 2011).

This qualitative descriptive study used resilience as a conceptual framework which proposes that resilience is the interplay between risk factors and protective factors in the face of adversity (Luthar, and permission has been granted for this version to appear in e-Publications@Marquette. Informa Healthcare does not grant permission for this article to be further copied/distributed or hosted elsewhere without the express permission from Informa Healthcare. 
Cicchetti, \& Becker, 2000; Sandelowski, 2000; Sandelowski, 2010). Risk factors are factors that influence a person's coping, predispose them to stress, and can lead to physical and psychological health problems if not well managed (Greene, Galambos, \& Lee, 2003; Smith-Osborne, 2007). In fact, research on resilience has defined risk in a variety of ways including socio economic factors, an accumulation of events and divorce. Over time these factors increase the risk of poor development in "psychosocial competence, psychopathology and health" (Masten, 2001). More specifically, Masten defined risk as "established predictors of undesirable outcomes, where there is evidence suggesting a higher-than-usual probability of future problem" (Masten, 2014). Protective factors, on the other hand, can buffer the effects of risk factors, decrease their influence, prevent the occurrence of physical and health problems, and can lead to positive health outcomes (Bekhet, Johnson, \& Zauszniewski, 2012; Zauszniewski, Bekhet, \& Suresky, 2010; M. Rutter, 1987).

The purpose of this descriptive qualitative study is to explore components of resilience (i.e., risk and protective factors) in adolescents who survived a suicide attempt from the perspective of the nurses working on two adolescent inpatient psychiatric units. The perspectives gained from this study will be used to develop future nursing interventions to help adolescents overcome their risk factors and to build on their protective factors. Ultimately, by increasing resiliency in this population, death by suicide has the potential to greatly decrease.

\section{Methods}

\section{Participants}

The study included one focus group with nine registered nurses from two facilities working on an adolescent inpatient psychiatric unit for a minimum of 6 months to 30 years. All of the nurses had experiences working with adolescent inpatients admitted for a suicide attempt. The participants ages ranged from 22 to 64 years old and they worked full-time or a combination of full and part time. Both of the psychiatric hospitals were located in urban areas. One of the hospitals was a 22 bed inpatient adolescent unit for patients from 13- 
NOT THE PUBLISHED VERSION; this is the author's final, peer-reviewed manuscript. The published version may be accessed by following the link in the citation at the bottom of the page.

17 years old. The other psychiatric hospital was a 23 bed child and adolescent unit for patients from 5-18 years of age.

\section{Procedure}

Institutional Research Board (IRB) approval was obtained from Marquette University in Milwaukee, Wisconsin. IRB-approved fliers were distributed on the psychiatric units. Recruitment also occurred at staff meetings where the PI (principal investigator) discussed the aim of the study and distributed a voluntary sign-up sheet. The participants who were interested contacted the PI directly via telephone or provided information on the sign-up sheet during a staff meeting. The PI contacted each participant individually and selected a mutually agreed upon date and time for the focus group. The focus group occurred in a conference room on a different floor than the inpatient units at one of the two psychiatric hospitals. Prior to initiating the focus group, each participant completed a demographic sheet, read an information sheet regarding consenting to the focus group and selected a name tag. Pre-written name tags with names other than the participants were used for identification during the study to maintain confidentiality for the participants.

Seven questions were asked (Appendix 1) to nine registered nurses during a one-time 2 hour focus group. The PI led the focus group and the co-investigator was present for providing insights and clarification for the duration of the audio recording. The audio recording was professionally transcribed onto a Microsoft Word document. The participants received a $\$ 30$ gift card of their choice to thank them for their time and contributions. Food and refreshments were available at the beginning of the session and during a 10-minute break in between to promote the cohesiveness of the group.

\section{Data Analysis}

The audio recordings were transcribed verbatim and assessed for accuracy in the interpretation by the researchers. The transcriptions were analyzed by the PI and co-investigator for common themes that emerged. The researchers used content analysis; subcategories were independently identified in each of the three 
categories. The three categories are: risk factors, protective factors, and proposed nursing interventions by linking reoccurring codes (Graneheim \& Lundman, 2004). The process of sharing stories in a small group facilitated the nurses' ability to give meaning to their experiences concerning observed risk and protective factors and nursing intervention strategies that could enhance resilience among adolescents who attempted suicide.

To ensure the trustworthiness of the findings, the two authors reviewed, discussed, refined the themes, and confirmed the analysis. The credibility of the data was enhanced by independent coding of the data (with an agreement exceeding 95\% while comparing the coding schemes), categorization, and conceptual dimensions determined independently by the researchers (Glaser, 1992). Credibility and truthfulness of this current research was enhanced through the use of quotations that reflect the accurate descriptions of nurses' experiences (Guba \& Lincoln, 1989). These findings fit contexts outside the current research situation and are meaningful; therefore, "fittingness," which is equal to external validity in quantitative research, was achieved. Saturation was achieved as there was redundancy and as no new themes arose from the nurses' experiences (Guba \& Lincoln, 1989).

\section{Results}

\section{Demographics}

Eleven registered nurses meeting the research criteria were recruited into the study, one withdrew due to a scheduling conflict and another participant did not attend the focus group. All of the participants were Caucasian females; although invited, no males or nurses of other ethnicities volunteered for the study.

\section{Themes of Risk Factors, Protective Factors, and Proposed Integration into the Nursing Practice from the Nurses' Perspectives}

On analysis of the focus group responses, three overarching categories emerged including risk factors, protective factors, and future recommendations of suicide prevention strategies (Table 2). and permission has been granted for this version to appear in e-Publications@Marquette. Informa Healthcare does not grant permission for this article to be further copied/distributed or hosted elsewhere without the express permission from Informa Healthcare. 
NOT THE PUBLISHED VERSION; this is the author's final, peer-reviewed manuscript. The published version may be accessed by following the link in the citation at the bottom of the page.

Table 1. Resilience in Adolescents Who Survived a Suicide Attempted

\section{Category Risk Factors}

Sub-

category
Unstable households and traumatized childhood history

Having a means to drugs and firearms

Bullying

Cognitive distortions and lack of vision for the future

Absence of parental bonding and lack of positive role model

Poor self-esteem and issues with identity

\section{Protective Factors}

Connection with others

Having future plan

Faith

Expression of feelings and Decreasing stigma communicating stressful thoughts

$\begin{array}{ll}\text { Having future plan } & \begin{array}{l}\text { Better suicide } \\ \text { assessment and } \\ \text { suicide intervention } \\ \text { plan } \\ \text { Treating the whole } \\ \text { paith }\end{array} \\ \begin{array}{l}\text { Expression of feelings and } \\ \text { communicating stressful } \\ \text { thoughts }\end{array} & \end{array}$

Nursing Practice

Discharge Preparation

Better suicide assessment and suicide intervention plan

Treating the whole person

\author{
.
}

d

\title{
Risk Factors
}

Six subcategories were identified as risk factors for adolescents attempting suicide; "unstable households and traumatized childhood history," "having a means to drugs and firearms," victims of "bullying," "cognitive distortions and lack of vision for the future," "absence of parental bonding and lack of positive role model," and "poor selfesteem and issues with identity" (Table 1).

\section{Subcategory 1: Unstable Households and Traumatized Childhood History}

The subcategory "unstable households" mainly referenced unpredictable events occurring in the household including experiencing a trauma during childhood. One nurse pointed out that "Definitely a broken family structure is pretty significant most of the time... even if it is $a[n]$ intact family, there's still a lot of family stressors going on, either financial difficulties or domestic abuse in the home." Another nurse elaborated in stating, "I've noticed that many of the adolescents have a significant trauma history. They have multiple adverse childhood experiences...Those that have been raised in foster care and have attachment problems, and [have] been passed around frequently throughout their life." 
NOT THE PUBLISHED VERSION; this is the author's final, peer-reviewed manuscript. The published version may be accessed by following the link in the citation at the bottom of the page.

\section{Subcategory 2: Having a Means to Drugs and Firearms}

Using substances or having access to alcohol, drugs, prescription medication, or firearms were risk factors for suicide attempts. One participant indicated, "They have a means, that there are prescription drugs around the house or even just mass quantities of Benadryl and Tylenol. We have been seeing that very frequently." Another nurse confirmed this, stating "Sometimes they claim they're taking these things but they don't really know what's in the drugs. Even Benadryl, Tylenol...not being monitored and they take handfuls [of drugs] with the intention of killing themselves." In congruence with other participants, one nurse pointed out, "Access to means, such as adults having guns in the home or prescription medications that are ... laying around."

\section{Subcategory 3: Bullying}

Many of the nurses recognized bullying by peers as a significant risk factor for adolescents attempting suicide. One nurse described the act of being bullied with a co-occurring perception of humiliation, "There seems to be a lot [of adolescents] that have been significantly bullied and humiliated. I think humiliation is, I would pick that almost as the top factor, which ... crosses all socioeconomic levels... Teens who are ostracized from their peers as well and their family [are at risk for attempting suicide]." Bullying was also described in the form of social media or cyber-bullying, "I guess one of the biggest things that I see is the social media. Kids who are bullied at school-when we were all kids growing up and got bullied at school, you could go home and more or less escape it ... maybe be teased by other, your other siblings, but that's ... where it stopped. Nowadays it doesn't stop at all, especially with the social media, Facebook, Twitter, the bullying continues. And they just ... get beaten down to such a level that ... they begin to believe what's been said about them. And so their self-esteem goes right down the tubes."

Table 2. Summary of Categories Expressed by Inpatient Psychiatric Nurses

\section{Category}

Risk Factors

\section{Sub-category}

Unstable households and traumatized childhood history

\section{Example}

"I've noticed that many of the adolescents have a significant trauma history. They have multiple adverse childhood experiences..."

Issues in Mental Health Nursing, Vol 37, No. 11 (November 2016): pg. 839-846. DOI. This article is @ Informa Healthcare and permission has been granted for this version to appear in e-Publications@Marquette. Informa Healthcare does not grant permission for this article to be further copied/distributed or hosted elsewhere without the express permission from Informa Healthcare. 
NOT THE PUBLISHED VERSION; this is the author's final, peer-reviewed manuscript. The published version may be accessed by following the link in the citation at the bottom of the page.

\section{Category}

Protective Factors Connection with others

Future plans

Faith
Sub-category

Having a means to drugs and drug use

Bullying

Cognitive distortions the future

Absence of parental bonding and lack of positive role model

Poor self-esteem and issues with identity and lack of vision for

\section{Example}

"They have a means, that there are prescription drugs around the house or even just mass quantities of Benadryl and Tylenol..."unlocked and unmonitored firearms..."

"There seems to be a lot [of adolescents] that have been significantly bullied and humiliated."

"A lot of kids that have come in with suicide attempts are very concrete thinkers. Where it's all or nothing, either I do very well in school or I am a complete failure."

"...adults may not be home or maybe they're home but they're drunk or they're using drugs."

"Poor self-esteem seems to be a commonality...a lot of gender issues come up..."

"They have other healthy adults they have access to if the parents are not available, such as a youth pastor, an uncle, or grandparent."

"Some of the ideas that I had for [protective factors] were goal for the future..."

"...they have faith that there is something bigger that is able and willing to help them..."

Expression of feelings "... they are able to articulate and use and communicating language well to express what they're stressful thoughts

Future Discharge Recommendation preparation

Better suicide assessment and suicide intervention plan

Treating the whole person

Decreasing stigma feeling and also what they need. Being able to ask for help."

"Setting them up with a realistic plan, having these coping skills in place and having them understand how and when [it] is appropriate to use them."

"...every nurse needs to be comfortable doing this...You're supposed to be, you're asked about suicide."

"In nursing school we're taught to take care of the whole patient rather than just the disease this isn't the G.I. patient or this is an orthopedic case, it's a person. It's more than just the diagnosis."

"There's a bit of a stigma against psych nursing, that there's a little bit of, you're not quite a real nurse." supposed to, every point of contact, be 
NOT THE PUBLISHED VERSION; this is the author's final, peer-reviewed manuscript. The published version may be accessed by following the link in the citation at the bottom of the page.

\section{Subcategory 4: Cognitive Distortions and Lack of Vision for the Future}

A vast majority of the nurses concluded another risk factor as "cognitive distortions and lack of vision for the future." One nurse provided the following response: "A lot of kids that have come in with suicide attempts are very concrete thinkers. Where it's all or nothing, either I do very well in school or I am a complete failure. So if I get an A minus I let my parents down [and] I let myself down. They can't see past the next hour, so making long-term goals is very difficult for them...getting through the next week of school, the next two weeks of school, or the next day of treatment is very hard." Another nurse pointed out "Also [a] lack of ... future orientation, that was mentioned before, they're just kind of like, nothing is ever gonna get better. Or they are like, I'm 16, I don't get to move out until I'm 18, I can't make it another two years."

\section{Subcategory 5: Absence of Parental Bonding and Lack of Positive Role Model}

One recurring code was adolescents lacking parental bonding or a positive role model. The following are two examples: "I would say lack of positive adult role models ... adults may not be home or maybe they're home but they're drunk or they're using drugs ... [Parents] not interacting with the adolescents in a way that would prevent them from doing something like that" and "Losing parental figures. We've had a couple [adolescents] recently that ... don't have their parents. Either [their parents] are not present 'cause they're incarcerated, or they've died from overdose ... they now have whoever their parental figure is ... dying from terminal cancer. So they ... are like, 'That's it. Everyone that's ever gotten close to me is dying, I'm just going to cut the loss and cut the pain and just take care of myself before I have to feel it again'... I have [also] seen a couple times a negative attention seeking [behavior]... the only time their parents actually pay attention to them is when they're ... doing something to try to hurt themselves. So they do it to get attention because when they start doing well then [their] parents are like, 'Oh, well now that you're doing okay, we're going to go do X, Y, and Z, and you can stay here.' And they're like, 
NOT THE PUBLISHED VERSION; this is the author's final, peer-reviewed manuscript. The published version may be accessed by following the link in the citation at the bottom of the page.

'Well what the heck.' ... they're like, 'Well I'll try killing myself again'... unfortunately, it kind of turns into a vicious circle of that [pattern]."

\section{Subcategory 6: Poor Self-Esteem and Issues with Identity}

Poor self-esteem and issues with identity were contributing risk factors for a suicide attempt according to the nursing staff. The nurses discussed issues with sexual and gender identity, as one nurse stated "Poor self-esteem seems to be a commonality...a lot of gender issues come up, if they are thinking they are another gender or they're struggling with their sexuality." In regards to their relationships one nurse responded, "Lack of identity...Their identity is wrapped up in their boyfriend, girlfriend ... their significant other. When that person leaves they're like 'I don't have anything left.' And it's like, 'Well you're still you,' but they just qualify themselves as the boyfriend or the girlfriend. Without having that other individual available to them, they ... don't have any sense of who they are."

\section{Protective Factors}

For the second category, protective factors, the following subcategories were identified: "connection with others," "having future plans," "faith," and "expression of feelings and communicating stressful thoughts." Nurses are in a position to help build protective factors through nursing interventions which can increase resiliency in adolescent patients (Table 1).

\section{Subcategory 1: Connection with Others}

The nurses indicated that a connection with at least one other person in his or her life is an important form of protection from a suicide attempt and/or completion. According to the nurses, these connections can be obtained through a parent, peer, supportive adult, or online. One nurse stated: "Teens who have siblings that they live with and they're connected with. When they reflect on the impact on their sibling if they would kill themselves, I believe that's a protective factor...they can distance themselves from chaos and dysfunction that's going on around them. They have other healthy adults they have access to if the parents are not available, such as a youth pastor, an uncle, or grandparent." and permission has been granted for this version to appear in e-Publications@Marquette. Informa Healthcare does not grant permission for this article to be further copied/distributed or hosted elsewhere without the express permission from Informa Healthcare. 
NOT THE PUBLISHED VERSION; this is the author's final, peer-reviewed manuscript. The published version may be accessed by following the link in the citation at the bottom of the page.

\section{Subcategory 2: Future Plans}

Another protective factor discussed by the nurses was future plans to look forward to accomplishing. The anticipation of future events ranged from more complex planning such as a future vacation to a simplistic one, as having a favorite food for lunch. The anticipation for plans included a future vacation, involvement on sports teams, church group events, spending time outside, and social activities. One nurse stated, "Some of the ideas that I had for [protective factors] were [having a] goal for the future, having a career goal... it seems like the people that say their reasons for living are affecting other people or helping others seem to ... [be] a little bit happier.

Participation in interactive social activities like a church group, sports, something where they're not just sitting and looking at a screen and pressing buttons seems to build identity more and happiness." Another nurse emphasized the importance of even more simple planning, "Sometimes it's really simple things to get them from hour to hour, like I like the taste of strawberries and I'm going to have strawberries at lunch, that'll get them to ... the next hour."

\section{Subcategory 3: Faith}

Some nurses discussed faith or a belief in a higher power as a protective factor. Examples from one of the nurses included "I believe that adolescents who have some sense of transcendence, they have faith that there is something bigger that is able and willing to help them, and that also they have a sense of unconditional acceptance from their object of faith."

\section{Subcategory 4: Expression of Feelings and Communicating Stressful Thoughts}

Expression of feelings and communicating stressful thoughts was discussed by some of the nurses as being an important protective factor. One nurse stated "Once a patient has ...maybe... tried to commit suicide...the parents can become more aware of what's going on and communication can improve between the family and the child." Another nurse discussing communication as a protective factor said, "They are able to articulate and use language well to express what they're feeling and also what they need ...being able to ask for help."

Issues in Mental Health Nursing, Vol 37, No. 11 (November 2016): pg. 839-846. DOI. This article is @ Informa Healthcare and permission has been granted for this version to appear in e-Publications@Marquette. Informa Healthcare does not grant permission for this article to be further copied/distributed or hosted elsewhere without the express permission from Informa Healthcare. 


\section{Effective Nursing Interventions to Manage and Prevent Present and Future Suicidal Attempts}

\section{Subcategory 1: Discharge Preparation}

Nurses play a significant role in preparing the adolescent for discharge through communicating available resources early in the patient's stay, reinforcing coping strategies and the use of medication and outpatient therapy. The nurses emphasized the importance of a personalized and realistic treatment plan where an adolescent is given real-world examples in preparation for discharge. One nurse stated, "Setting them up with a realistic plan, having these coping skills in place and having them understand how and when [it] is appropriate to use them. Having the family and the patient have the knowledge of their medications, their side effects, how they are used, knowing that they need to continue to take them ... That their disease, most of their disease process are ongoing... making sure that the parents or whoever they're going home with really understand the signs of relapse so they can ...maybe... catch it earlier than later. So it doesn't ...maybe... get to the full-blown suicide attempt." Yet, another nurse pointed out, "Often when these kids come in here they have no idea how long they're gonna be here, how many days, and it's really confusing to them. Then all of the sudden one day the doctor says 'okay, you're ready' and it comes to a surprise. I think as nurses...you know...we need to be advocating and at the forefront shaping expectations, helping the kids see their success from day to day, or what they need to learn more about and help shape that and get them ready for discharge ... once they do go, if they have to come back it's okay, it's okay, come back."

\section{Subcategory 2: Better Suicide Assessment and Suicide Intervention Plan}

The nurses articulated the need for better training of nonmental health nursing staff, assessment at every point of care, earlier identification of needs for a suicide assessment and a better guide for a patient at risk for attempting suicide. For universities who do not have mental health clinical, students often gain exposure to patients with psychiatric issues/disorders through their other mandated clinical and permission has been granted for this version to appear in e-Publications@Marquette. Informa Healthcare does not grant permission for this article to be further copied/distributed or hosted elsewhere without the express permission from Informa Healthcare. 
rotations. Unfortunately, as one nurse described, there is the lack of knowledge for the care and assessment for suicide. "There was a case when I was on a med-surg floor, and there had been a patient that was in the hospital for a total of two weeks at this particular facility and one before that for some gastrointestinal issues ... I asked her point blank, 'are you feeling suicidal'? She said, 'yes'. I said do you have a plan? She said 'yes, I'm going to overdose on my insulin when I go home'... this is my third semester nursing school, so we hadn't even gotten to psych quite yet ... All of this stuff is coming out and I'm standing there like 'what the heck, no one's noticed this for two weeks...there was no record of it, nothing'... I got her plan... I asked her if she felt safe at certain places. She gave me a contact to someone who she actually feels like she can trust. All this information, and I ungowned, walk out of the room, I tell the nurse, who's actually working there. 'Oh okay, well I guess we might have to call psych'. I'm like, she has a plan, she point blank told me this and none of you guys have told because unfortunately I think it's because it was med surg and there's so much going on, no one had actually just stood in there and talked with her." Yet another nurse stated "... every nurse needs to be comfortable doing this...You're supposed to be, you're supposed to, every point of contact, be asked about suicide."

Another nurse pointed out, "One of these things that I find really difficult is when we get a patient that comes in, if they've gone through the medical clearance, they are being asked this group of questions regarding the nursing admission, admission assessment. Then they go to the admissions department and they are pretty much asking them the same questions, then they come to us...At some point along the way the patient, I think, gets incredibly frustrated and they shut down...I had a 20 year old that I just admitted this morning who is going to (name of university). She felt like killing herself and it was over a (subject) exam, that she may be failing (subject). She was going to jump out of a window, 12 or 19 stories up. Yet when you ask her these questions as to ... you know...trying to find the severity within the suicide assessment, it was very minimal. And then you ask her, do you have any thoughts of suicide now? 'Yeah.' Do you feel that you need to be here? 'No, not really.' And then you bring them back to the reality of saying, "Hey, wait a minute. You wanted to jump out of a 19 story building, that's not something that somebody just randomly thinks about."

Issues in Mental Health Nursing, Vol 37, No. 11 (November 2016): pg. 839-846. DOI. This article is @ Informa Healthcare and permission has been granted for this version to appear in e-Publications@Marquette. Informa Healthcare does not grant permission for this article to be further copied/distributed or hosted elsewhere without the express permission from Informa Healthcare. 
NOT THE PUBLISHED VERSION; this is the author's final, peer-reviewed manuscript. The published version may be accessed by following the link in the citation at the bottom of the page.

\section{Subcategory 3: Treating the Whole Person}

The nurses discussed the need for treating the whole person not just the patients' diagnosis or disease. One nurse shared her experience stating that "In nursing school we're taught to take care of the whole patient rather than just the disease. This isn't the G.I. patient or this is an orthopedic case, it's a person. It's more than just the diagnosis."

\section{Subcategory 4: Decreasing Stigma}

The nurses saw a need for decreasing stigma of mental illness in the schools, communities, and society as a whole. Two nurses pointed out "Teaching everyone to decrease the stigma, not just us in the healthcare field but in general because I think it's an unknown thing. Even in nursing school prior to going into psych nursing, it's kind of a vague thing" and "The overwhelming stigma. ...There's a bit of a stigma against psych nursing, that there's a little bit of, you're not quite a real nurse. And I think that should, I don't know, be addressed somewhere. You're not constantly doing the IV's and chest compressions generally speaking but I would really like an ER nurse or med-surg nurse run our milieus."

\section{Discussion}

This study is the first to explore the risk and protective factors as indicators of resilience in adolescents who survived a suicide attempt from the perspective of registered nurses working in psychiatric facilities. The results of this study indicated that risk factors for adolescents attempting suicide were "unstable households and traumatized childhood history," "having a means to drugs and firearms," "bullying," "cognitive distortions and lack of vision for the future," "absence of parental bonding and lack of positive role model," and "poor self-esteem and issues with identity." The results of this study are, in part, in accordance with the Centers for Disease Control and Prevention (CDC, 2015b) report on preventing suicide, which recognized access to lethal means and a history of violence as risk factors for suicide. The nurses in this study identified additional risk factors including: bullying, impaired parent-child relationships, and permission has been granted for this version to appear in e-Publications@Marquette. Informa Healthcare does not grant permission for this article to be further copied/distributed or hosted elsewhere without the express permission from Informa Healthcare. 
cognitive distortions, lack of vision of the future, poor self-esteem, and issues with identity. Having a connection with one's family was found to be a protective factor against suicide in adolescent students (Resnick et al., 1997). This, in fact, supports the finding of "absence of parental bonding" as a risk factor for suicide in our study. Another study conducted by Gillman Kim, Alder, and Durrant (2006) found an increased risk for suicidal ideation in college students among those who have experienced emotional abuse, assault, and unwanted sexual touching. These findings, indeed, support our findings of the risk factor "traumatized childhood history."

The protective factors identified in this study were "connection with others," "future plans," "faith," and "expression of feelings and communicating stressful thoughts." These protective factors have the potential to foster greater connections for the individuals and prevent future suicide attempts and completion. They are directly in line with the current aim of the CDC's (2013) strategic planning for prevention of suicide but offer specific areas of focus for evaluation of protective factors. The CDC's goal for suicide prevention is to increase connectedness between individuals by increasing social contact and decreasing isolation, increasing the connection with the community as well as community organizations (CDC, 2013). Southwick and Charney (2012) also discussed the concept of connectedness in the form of social support. They indicated that high levels of social support increase self-esteem, "active problem-focused solving" and resiliency, which in fact were identified in this study as risk factors for suicide. One study indicated the need to connect suicidal youth with the social support available to them during a time when their perception lacks the ability for the adolescent to utilize social supports (Rutter, Freedenthal, \& Osman, 2008). Nurses are in a strategic position to establish a relationship with their patients, seek out social support available and assist in fostering protective factors. ${ }^{\text {TABLE }} 2$

The recommendations for practice that were discussed by the nurses included: "discharge preparation," "better suicide assessment and suicide intervention plan," "treating the whole person," and "decreasing stigma." The themes identified by the nurses in this study are congruent with the National Strategy for Suicide Prevention (NSSP). The NSSP recognized the need to enhance training for identification of risk factors and proper referral, decreasing stigma, and permission has been granted for this version to appear in e-Publications@Marquette. Informa Healthcare does not grant permission for this article to be further copied/distributed or hosted elsewhere without the express permission from Informa Healthcare. 
and building relationships for adolescents in the prevention of suicide (CDC, 2015a).

The recent trend of diminishing mental health clinical sites for nursing students nationwide will decrease exposure to patients experiencing acute suicidality for the next generation of nurses. As a matter of fact, the majority of the nurses in this study did not have a mental health clinical rotation and the three nurses who had a mental health clinical did not feel adequately prepared to work with the psychiatric inpatient population. A study conducted by Ketola and Stein (2013) found that initially $99 \%$ of students were fearful of working with individuals with mental illness. However, after completing a mental health clinical rotation, roughly half $(47 \%)$ were able to relate to the individuals with mental illness and had a decreased fear of individuals with a mental health condition (Ketola \& Stein, 2013). Similarly, Happell's (2008a) study using responses from 687 undergraduate nursing students before and after their mental health clinical found that the clinical experience increased confidence in the mental health field. Also, there was a positive correlation between students feeling more prepared to work in mental health and choosing mental health as a career as a result of an exposure to mental health clinical (Happell, 2008b). Consequently, one way to decrease the negative stigma of mental illness and foster better suicide assessment is to increase students' exposure to mental health settings, which in turn will impact the quality of care.

Nursing interventions play a role in fostering resilience in family members with mental illness (Zauszniewski et al., 2010). Examples of interventions that might foster resilience in the light of the study findings include: providing support, promote expression of feelings, and keep open lines of communication. Also, there is a need for a better suicide assessment and clear guidelines for nursing actions when a patient indicates they are suicidal. Nursing staff are in a strategic position to establish a relationship with patients beyond the inpatient setting by providing effective interventions at every point of care.

The limitations of this study were a lack of male nurses and nurses of other ethnic background perspectives. Another limitation was the small sample size of the focus group. Future research should and permission has been granted for this version to appear in e-Publications@Marquette. Informa Healthcare does not grant permission for this article to be further copied/distributed or hosted elsewhere without the express permission from Informa Healthcare. 
include a larger sample as well as include male nurses and nurses of other ethnic backgrounds to represent their perspectives. Despite its limitations, the findings of the study provide direction toward promoting resiliency in adolescents in order to decrease suicide and enhance their quality of life.

There is a clear need to decrease risk factors. Primary prevention through school programs can protect adolescents from using drugs, increase healthy connections with teachers, peers, and coaches, and help them to create a future life meaning. These programs have the potential to be initiated prior to the adolescent being discharged. As indicated in the literature, there is a concern with a lack of information on the adolescents not in the school system (Resnick, Ireland, \& Borowski, 2004; Walsh \& Eggert, 2007). The nursing staff has the potential to access adolescents not in the school system yet at high risk through inpatient admissions. In identifying and decreasing risk factors while increasing protective factors, nurses are in a powerful position to foster resiliency in this population. There is a need for future studies on effective nursing interventions to be implemented in practice to increase resiliency for adolescents with a focus on suicide prevention. The guide could ultimately become a policy for fostering resiliency in the adolescent population through the factors found in the study.

Declaration of Interest: The authors report no conflict of interest. The authors alone are responsible for the content and writing of this paper.

\section{References}

American Foundation for Suicide Prevention. (2015). Facts and figures. Retrieved from http://www.afsp.org/understanding-suicide/facts-andfigures

Bekhet, A., ElGuenidi, M., \& Zauszniewski, J. A. (2011). The effects of positive cognitions on the relationship between alienation and resourcefulness in nursing students in Egypt. Issues in Mental Health Nursing, 32, 3541.

Bekhet, A. K., Johnson, N. L., \& Zauszniewski, J. A. (2012). Resilience in family members of persons with autism spectrum disorder: A review of the literature. Issues in Mental Health Nursing, 33(10), 650-656.

Blakemore, S-J., Burnett, S., \& Dahl, R. E. (2010). The role of puberty in the developing adolescent brain. Human Brain Mapping, 31, 926-933. 
NOT THE PUBLISHED VERSION; this is the author's final, peer-reviewed manuscript. The published version may be accessed by following the link in the citation at the bottom of the page.

Centers for Disease Control and Prevention (CDC). (2013). Connectedness as a strategic direction for the prevention of suicidal behavior. Retrieved from

http://www.cdc.gov/violenceprevention/pdf/Suicide Strategic Directio -One-Pager-a.pdf

Centers for Disease Control and Prevention (CDC). (2015a). Suicide trends among persons aged 10-24 years-United States, 1994-2012.

Retrieved from http://www.cdc.gov/mmwr/preview/mmwrhtml/mm6408a1.htm

Centers for Disease Control and Prevention (CDC). (2015b). Preventing Suicide. Retrieved from http://www.cdc.gov/features/preventingsuicide/

Fitzpatrick, J. (2015). A national tragedy: Increases in death by suicide, decreases in other major causes of death. Archives of Psychiatric Nursing, 29(2), 75.

Gillman, J. L., Kim, H. S., Alder, S. C., \& Durrant, L. H. (2006). Journal of American College Health, 55(1), 17-26.

Glaser, B. G. (1992). Basics of grounded theory analysis. Mill Valley, CA: Sociology Press.

Graneheim, U. H., \& Lundman, B. (2004). Qualitative content analysis in nursing research: Concepts, procedures and measures to achieve trustworthiness. Nursing Education Today, 24(2), 105-112

Greene, R. R., Galambos, C., \& Lee, Y. (2003). Resiliency theory: Theoretical and professional conceptualizations. Journal of Human Behavior in the Social Environment, 8(4), 75-91.

Guba, E. G., \& Lincoln, Y. S. (1989). Fourth generation evaluation. Newbury Park, CA: Sage.

Happell, B. (2008a). The importance of clinical experience for mental health nursing-Part 1: Undergraduate nursing students' attitudes, preparedness and satisfaction. International Journal of Mental Health Nursing, 17, 326-332.

Happell, B. (2008b). The importance of clinical experience for mental health nursing-Part 2: Relationships between undergraduate nursing students' attitudes, preparedness, and satisfaction. International Journal of Mental Health Nursing, 17, 333-340.

Ketola, J., \& Stein, J. V. (2013). Psychiatric clinical course strengthens the student-patient relationships of baccalaureate nursing students. Journal of Psychiatric and Mental Health Nursing, 20, 23-34.

Luthar, S. S., Cicchetti, D., \& Becker, B. (2000). The construct of resilience: A critical evaluation and guidelines for future work. Child Development, 71(3), 543-662.

Masten, A. S. (2014). Ordinary magic: Resilience in development. New York, NY: Gilford.

Issues in Mental Health Nursing, Vol 37, No. 11 (November 2016): pg. 839-846. DOI. This article is @ Informa Healthcare and permission has been granted for this version to appear in e-Publications@Marquette. Informa Healthcare does not grant permission for this article to be further copied/distributed or hosted elsewhere without the express permission from Informa Healthcare. 
NOT THE PUBLISHED VERSION; this is the author's final, peer-reviewed manuscript. The published version may be accessed by following the link in the citation at the bottom of the page.

Masten, A. S. (2001). Ordinary magic resilience process in development. American Psychologist, 56(3), 227-238.

National Institutes of Health (NIH). (2011). The teen brain: Still under construction. Retrieved from http://www.nimh.nih.gov/health/publications/the-teen-brain-stillunder-construction/index.shtml

Resnick, M. D., Ireland, M., \& Borowski, I. (2004). Youth violence perpetration: What protects? What predicts? Findings from the National Longitudinal Study of Adolescent Health. Journal of Adolescent Health, 35(5), 424e1-424e10.

Resnick, M. D., Bearman, P. S., Blum, R. W., Bauman, K. E., Harris, K. M., Jones, J., ... Udry, J.R. (1997). Protecting adolescents from harm findings from a national longitudinal study on adolescent health. The Journal of the American Medical Association, 278(10), 823-832.

Rutter, M. (1987). Psychosocial resilience and protective mechanisms. American Journal of Orthopsychiatry, 57(3), 316-331.

Rutter, P. A., Freedenthal, S., \& Osman, A. (2008). Assessing protection from suicidal risk: Psychometric properties of the suicide resilience inventory. Death Studies, 32, 142-153.

Sandelowski, M. (2000). Focus on research methods whatever happened to qualitative description? Research in Nursing \& Health, 23, 334-340.

Sandelowski, M. (2010). What's in a Name? Qualitative Description Revisited. Research in Nursing \& Health, 2010, 33, 77-84.

Smith-Osborne, A. (2007). Life span and resiliency theory: A critical review. Advances in Social Work, 8(1) 152-168.

Southwick, S. M., \& Charney, D. S. (2012). The science of resilience: Implications for the prevention and treatment of depression. Science, 338,79-82.

Streubert, H. J., \& Carpenter, D. R. (1999). Qualitative research in nursing: Advancing the humanistic imperative. ( $2^{\text {nd }}$ ed.). Philadelphia, PA: Lippincott.

United States Census Bureau. (2012). Retrieved from http://www.census.gov/ population/age/data/2012comp.html

Walsh, E., \& Eggert, L. L. (2007). Suicide risk and protective factors among youth experiencing school difficulties. International Journal for Mental Health Nursing, 16(5), 349-359.

World Health Organization (WHO). (2013). Adolescent Health. Retrieved from http://www.who.int/topics/adolescent health/en/

World Health Organization (WHO). (2015). Adolescent development. Retrieved from http://www.who.int/maternal child adolescent/topics/ adolescence/dev/en/

Issues in Mental Health Nursing, Vol 37, No. 11 (November 2016): pg. 839-846. DOI. This article is @ Informa Healthcare and permission has been granted for this version to appear in e-Publications@Marquette. Informa Healthcare does not grant permission for this article to be further copied/distributed or hosted elsewhere without the express permission from Informa Healthcare. 
NOT THE PUBLISHED VERSION; this is the author's final, peer-reviewed manuscript. The published version may be accessed by following the link in the citation at the bottom of the page.

Zauszniewski, J., Bekhet, A., \& Suresky, M. J. (2010) Resilience in family members of persons with serious mental illness. Nursing Clinics of North America, 45(4), 1-19.

\section{APPENDIX A.}

\section{Focus Group Questions}

\section{Risk Factors:}

- Tell me about the commonalities of the adolescents you worked with who attempted suicide.

- When thinking back on the adolescents you worked with who attempted suicide, what factors do you see as increasing patients' risk factors for attempting or commiting suicide?

\section{Protective Factors:}

- When thinking back on the adolescents you worked with who attempted suicide, what factors do you see as increasing patients' protective factors against suicide?

\section{Nursing Interventions:}

- When patients come into your unit with suicidal ideation or intent what additional nursing interventions are helpful besides mandated suicide assessment?

- What nursing intervention(s) do you see being most effective in protecting your patients' from suicide once they leave?

- How could factors that enhance or hinder adolescents from attempting or committing suicide be integrated into nursing practice?

- What would be the best way to educate nurses on how to implement this into their practice? 